\title{
FARMASI KELAUTAN: MANFAAT RUMPUT LAUT DALAM KEHIDUPAN SEHARI-HARI
}

\section{MARINE PHARMACY: BENEFITS OF SEAWEED IN DAILY LIFE}

\author{
Riong Seulina Panjaitan*, Manuel Vesselaldo, Michael, Wawan Kurniawan
}

Universitas 17 Agustus 1945 Jakarta, Sunter, Jakarta Utara

*Email: riongpanjaitan@yahoo.co.id

(Diterima 27-06-2021; Disetujui 05-08-2021)

\begin{abstract}
ABSTRAK
Manfaat rumput laut sangat sedikit diketahui oleh masyarakat saat ini. Kendala dalam manfaat rumput laut salah satunya yaitu masyarakat umum kurang mengerti atau kurangnya sosialisasi mengenai rumput laut. Rumput laut banyak sekali manfaat yang dapat kita ketahui seperti untuk kecantikkan dan juga untuk kesehatan. Kegiatan pengabdian masyarakat mengenai manfaat rumput dalam kehidupan sehari-hari dilakukan dengan pemberian materi tentang agar, alginate, karagenan, jenis dan klasifikasi rumput laut dan memberikan beberapa manfaat yang ada dalam rumput laut serta cara budidaya rumput laut. Kegiatan diawali dengan pre-quesioner tentang pengetahuan rumput laut. Kegiatan dilanjutkan dengan pemberian materi serta diskusi. Setelah kegiatan selesai peserta melaksanakan post-quesioner untuk mengukur kemampuan anggota Himpunan Mahasiswa Farmasi Universitas Palangkaraya. Peserta Himpunan Mahasiswa Farmasi Universitas Palangkaraya mengalami peningkatan pengetahuan berdasarkan hasil pre-quesioner dan post-quesioner yang dilakukan dengan tentang agar, alginate dan karagenan, jenis dan klasifikasi rumput laut. Peserta memiliki keterampilan untuk bertanya tentang manfaat rumput laut dalam dunia kefarmasiaan.
\end{abstract}

Kata kunci: Rumput laut, manfaat, farmasi

\section{ABSTRACT}

The benefits of Seaweed are less known to the community today. Constraints in the benefits of seaweed, one of which is general, less understanding or lack of socialization on seaweed. Seaweed is a lot of benefits that can know as for beauty and also for health. Devotional service activities about the benefits of grass in daily work in the provision of material about agar, alginate, carrageenan, type and classification of seaweed and deep members and how to cultivate seaweed. Activities begins with pre-test about seaweed sewing. Activities followed by giving and discussion material. After the activity has finished the participants carrying out posttests to measure the ability of members of the Palangkaraya University Pharmacy Student Association. Participants in the University Pharmaceutical Student Association experienced an edit of equals based on the pre-test and post-test results with agar, alginate and seaweed classification. Participants have the appearance of asking about the benefits of seaweed wearing world pharmacies.

Keywords: seaweed, benefit, cultivation

\section{PENDAHULUAN}

Rumput laut atau lebih dikenal dengan sebutan seaweed merupakan salah satu sumber daya hayati yang sangat melimpah di perairan Indonesia. Keanekaragaman rumput laut di Indonesia merupakan yang terbesar dibandingkan dengan negara lain. Namun demikian, pemanfaatan rumput laut di Indonesia, terutama untuk keperluan industri dan kesehatan masih belum optimal. Rumput laut merupakan salah satu tumbuhan laut yang tergolong dalam makroalga benthik yang banyak hidup melekat di dasar perairan. Rumput laut merupakan ganggang yang hidup di laut dan tergolong dalam divisi thallophyta. Pada tahun 2005 dilaporkan bahwa konsumsi rumput laut bagi masyarakat Cina, Jepang, dan 
Korea mencapai 2 milyar US \$. Setiap hari sekitar 168 spesies alga telah dikomersilkan, di Jepang, Cina, Taiwan, dan Korea, diantaranya porphyra (nori), laminaria (kombu), undaria (wakame). Porphyra atau nori merupakan rumput laut yang paling populer di Jepang (Steinman, 2006). Contoh makanan yang terbuat dari rumput laut terkenal di Jepang adalah Kombu. Kombu terbuat dari rumput laut jenis Laminaria sp yang termasuk golongan kelp. Salah satu contoh kelp di Indonesia adalah Sargassum sp. Di berbagai belahan dunia, Sargassum sp merupakan jenis rumput laut di perairan tropis yang terkenal sebagai alginofit (penghasil alginat). Filipina, India dan Vietnam merupakan negara-negara yang mulai memanfaatkan rumput laut jenis ini.

Penanaman rumput laut yang ada di Indonesia sangat sedikit diterapkan, jika melihat kondisi geografis Indonesia maka Indonesia merupakan negara maritim dimana ukuran laut lebih besar dari pada ukuran daratan Indonesia. Jika dilihat dari kondisi tersebut seharusnya masyarakat Indonesia bisa memanfaatkan potensi dari laut tersebut. Kelebihan dari penanaman rumput laut ini adalah hemat, efisien dan perkembangannya yang cepat. Untuk memanen rumput laut hanya dibutuhkan waktu 30 hingga 45 hari.

Cara penanaman rumput laut ada 3 metode, yaitu: (1) metode dasar (bottom method), (2) metode lepas dasar (off-bottom method), dan (3) metode apung (floating method). Ketiga metode tersebut memiliki kelebihan dan kekurangannya masing-masing. Pemakaian metode juga ditentukan kondisi geografis dari laut atau pantai wilayah tersebut.

\section{BAHAN DAN METODE}

Pengabdian masyarakat ini dilakukan melalui media online yaitu zoom. Sasaran yang dipilih dalam kegiatan ini adalah Himpunan Mahasiswa Farmasi Universitas Muhammadiyah Palangkarya. Sebagai langkah dalam menambah pengetahuan Himpunan Mahasiswa Farmasi Universitas Muhammadiya Palangkarya mengenai Manfaat Rumput Laut Dalam Kehidupan Sehari-hari. Tim pelaksana yaitu para mahasiswa/i pada awal kegiatan mencari lokasi untuk melaksanakan pengabdian masyarakat. Selanjutnya tim pelaksana menentukan sasaran pengabdian masyarakat yaitu Himpunan Mahasiswa Farmasi Universitas Muhammadiyah Palangkarya. Sebelum kegiatan dilaksanakan terlebih dahulu menentukan dan mempersiapkan materi yang akan disampaikan dalam kegitan pengabdian masyarakat dalam Pengabdian Masyarkat. Evaluasi pada tahap ini ditujukan untuk mengetahui tingkat pemahaman para peserta disertai umpan balik berupa pertanyaan pertanyaan dari para tim pelaksana maupun peserta yang telah mendapatkan transfer pengetahuan terkait pentingnya "Manfaat Rumput Laut dalam Kehidupan Sehari-hari". 
Evaluasi pada akhir kegiatan ini dilakukan untuk mengukur keberhasilan dari seluruh rangkaian sosialisasi. Adapun keberhasilan dari kegiatan ini ditetapkan $80 \%$ peserta dalam kegiatan pelatihan ini dapat memahami sosialisasi serta diharapkan juga dapat diterapkan fungsi serta manfaat rumput laut dalam kehidupan sehari-hari.

\section{HASIL DAN PEMBAHASAN}

Kelompok dua farmasi kelautan telah melaksanakan kegiatan pengabdian masyarakat yang dilakukan melalui media online Google meet. Pengabdian masyarakat ini ditujukan untuk masyarakat Pulau Tidung, sebagai langkah menambah pengetahuan masyarakat Pulau Tidung tentang manfaat rumput laut dalam kehidupan sehari-hari, tim pelaksana sebelumnya telah mempersiapkan materi yang akan disampaikan dalam kegiatan pengabdian masyarakat Pulau Tidung. Setelah pemaparan materi yang telah dilaksanakan kelompok dua mempersiapkan pre-quesioner dan post-quesioner kepada masyarakat Pulau Tidung yang mengikuti kegiatan. Dari data yang didapatkan dari pelaksanaan pengabdian masyarakat Pulau Tidung tentang manfaat rumput laut dalam kehidupan sehari-hari adalah 55,9\% masyarakat Pulau Tidung mengetahui bahwa agar, alginate dan karagenan terbuat dari rumput laut dan 44,1\% masyarakat Pulau Tidung tidak mengetahui bahwa agar, alginate dan karagenan terbuat dari rumput laut.

Setelah mendengar penjelasan materi dari mahasiswa dan mahasiswi Universitas 17 Agustus 1945 data yang didapatkan melalui pre-quesioner dan post-quesioner, masyarakat Pulau Tidung mengetahui dan memahami tentang manfaat rumput laut dalam kehidupan sehari-hari dan mengetahui bahwa agar, alginate dan karagenan terbuat dari rumput laut.

Apakah anda mengetahui bahwa agar, alginat dan karagenan terbuat dari rumput laut? 59 responses

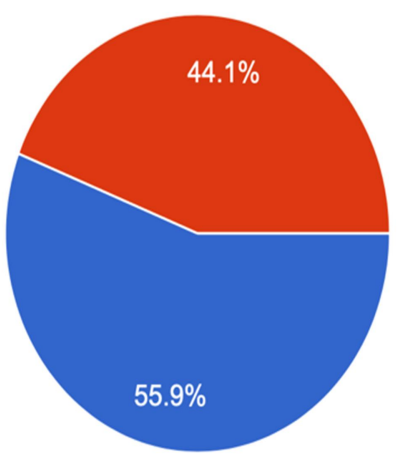

Ya, saya mengetahui

Tidak, saya tidak mengetahui 
Apakah anda mengetahui bahwa rumput laut dapat ditanam?

59 responses

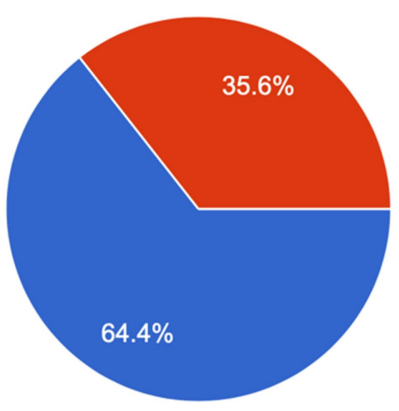

Ya, saya mengetahui

Tidak, saya tidak mengetahu

Gambar 1 dan 2. Pre-quesioner

Setelah mendengar penjelasan dari mahasiswa Universitas 17 Agustus, apakah saudara/i sudah mengetahui bahwa agar, alginat dan karagenan terbuat dari rumput laut?

43 responses

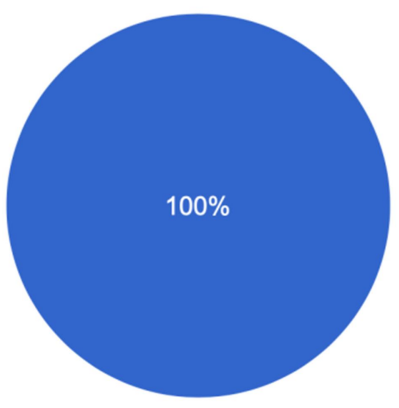

Ya, saya sudah mengetahui

Tidak, saya masih tidak memahami

Setelah mendengar penjelasan dari mahasiswa Universitas 17 Agustus, apakah saudara/i sudah mengetahui bahwa rumput laut dapat ditanam?

43 responses

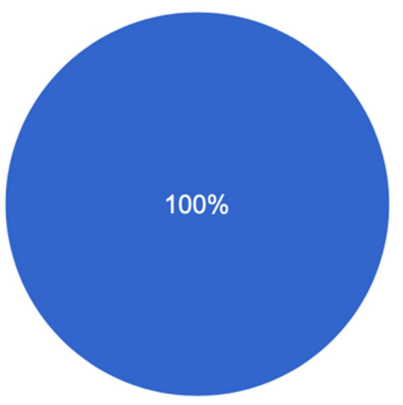

Ya, saya sudah mengetahui

Tidak, saya masih tidak memahami

Gambar 3 dan 4. Post-quesioner 
Dari hasil data yang ditunjukkan diketahui bahwa semua Mahasiswa Himpunan Farmasi Universitas Palangkarya sudah memahami bahwa rumput laut dapat diproses menjadi agar, alginat dan karagenan serta mahasiswa juga mengetahui bahwa rumput laut dapat dibudidayakan. Tetapi dari data di atas terdapat perbedaan jumlah mahasiswa yang mengisi pre-quesioner dan post-quesioner hal ini disebabkan adanya mahasiswa yang menjawab pre-quesioner sebanyak dua kali hal ini bisa dilihat dari nama yang tercantum pada google forms yang telah dibagikan.

\section{KESIMPULAN DAN SARAN}

Semua peserta yang mengikuti kegiatan kepada masyarakat yang dilaksanakan Mahasiswa Universitas 17 Agustus 1945 Jakarta pada mata kuliah Farmasi Kelautan telah mengetahui tentang manfaat rumput laut, olahan rumput laut serta cara budidaya rumput laut, hal ini dibuktikan oleh perbandingan questioner yang dibagikan sebelum dan sesudah kegiatan kepada masyarakat dimulai.

\section{UCAPAN TERIMA KASIH}

Terima kasih kepada Ketua Himpunan Farmasi Universitas Muhammadiyah Palangkarya yang telah memberikan waktunya kepada panitia untuk melaksanakan abdimas.

\section{DAFTAR PUSTAKA}

Abdullah, A. (2011). Budidaya Rumput Laut (Kappaphycus alvarezii) dengan Metode Rakit Apung di Desa Tanjung, Kecamatan Saronggi, Kabupaten Sumenep, Jawa Timur. Jurnal Ilmiah Perikanan dan Kelautan, 3 (1): 21-26.

E Afrianto, dan L. Evi. (1993). Budidaya Rumput Laut. Yogyakarta: Penerbit Kanisius.

Atmadja, W.S., Kadi, A., Sulistijo dan Rachmaniar. (1996). Pengenalan Jenis jenis Rumput Laut Indonesia. Puslitbang Oseanologi. Jakarta: LIPI Hlm. 56-152.

Chapman, V.J dan Chapman, D.J. (1980). Seaweeds and Their Uses. Third Edition. Chapman and Hall. 333 pp.

Raven, P, H. R, F, Evert dan S, E, Eichorn. (1986). Biology of Plants. Fourth Edition. Worth Publishers, Inc. New York. 775.

Soegiarto, A. Sulistijo. W, S, Atmaja dan H, Mubarak. (1978). Rumput Laut, Manfaat, Potensi damn Usaha Budidayanya. Jakarta: LON-LIPI.

Suparmi dan Sahri, A. (2020). Mengenal Potensi Rumput Laut: Kajian Pemanfaatan Sumber Daya Rumput Laut dari Aspek Industri dan Kesehatan. Sultan Agung. Vol 45 (118): 96-116

Winarno, F, G. (1996). Teknologi Pengolahan Rumput Laut. Jakarta: Pustaka Sinar Harapan 